\title{
Macroeconomic Effects of Adjustment Lending in Pakistan
}

\author{
ZAFAR IQBAL
}

\section{INTRODUCTION}

During the 1970s and early 1980s, many developing countries faced macroeconomic problems, notably large fiscal deficits, vulnerable balance of payments positions, increasing inflation rates, lower rates of domestic savings, and as a consequence lower capital formation and economic growth rates. The major financial lending institutions, preeminently the World Bank and the International Monetary Fund (IMF), argue that the present macroeconomic problems in less developed countries (LDCs) are due to structural maladjustments-poor economic policies and weak institutions. Therefore, since 1980, these donor agencies have been proposing Structural Adjustment Programmes (SAPs) and Sectoral Adjustment Programmes (SECAPs) associated with Structural Adjustment Lending (SALs) and Sectoral Adjustment Lending (SECALs), respectively. These programmes focus on broader macroeconomic adjustment policies. The disbursement of SALs and SECALs are, however, conditional upon the recipient countries adopting economic policies specified by the staff of the World Bank and the IMF.

Pakistan, like many other LDCs, also experienced a large fiscal deficit, rapid monetary expansion, accelerating inflation, an unsustainable current account deficit, deterioration in the terms of trade, and a large stock of external debt during the 1970s and 1980s. Pakistan is among those few countries that have received six or more adjustment loans since 1980. This paper provides an empirical analysis of Bank-IMF adjustment lending on Pakistan's key macroeconomic performance

Zafar Iqbal is Ph. D. Fellow at Centre, the Graduate School in Economics, Tilburg University, The Netherlands.

Author's Note: I am highly indebted to Professor Dr Jeffrey James and Dr Faiz Bilquees for their valuable comments on the earlier drafts of this paper. The present paper is an abridged version of the paper presented at the 10th Annual General Meeting of the Pakistan Society of Development Economists. Needless to say, I alone am responsible for any errors and omissions that remain. 
indicators using the latest available time-series data. The main focus of this paper is whether or not there is any direct connection between adjustment lending and Pakistan's key macroeconomic variables. Although, it would also be useful to analyse the effects of various important policies associated with the additional adjustment finance, this complex set of issues is beyond the scope of this paper.

The paper proceeds as follows. Section II describes the provision of additional adjustment lending to Pakistan. Section III details the methodology adopted and the main features of the data used in this study. Section IV provides an overview of macroeconomic performance indicators during the period 1970-79 (without adjustment) and 1980-91 (with adjustment). Section V discusses the empirical results. The final section offers concluding remarks.

\section{ADJUSTMENT LENDING IN PAKISTAN}

Aid packages provided to Pakistan under adjustment programmes are reported in Table 1. The structural adjustment loan (SAL) was granted in June 1982. The

Table 1

Adjustment Lending in Pakistan

(US \$ Million)

\begin{tabular}{lllrrrr}
\hline $\begin{array}{c}\text { Date of } \\
\text { Approval }\end{array}$ & \multicolumn{1}{c}{ Sectors } & $\begin{array}{c}\text { Type of } \\
\text { Lending }\end{array}$ & IBRD & IDA & IMF & Total \\
\hline 09-16-1980 & Fertiliser & SECAL & - & 50 & - & 50 \\
$06-01-1982$ & Structural Adjustment & SAL & 60 & 80 & - & 140 \\
$05-23-1985$ & Energy & SECAL & 178 & - & - & 178 \\
$05-27-1986$ & Export Development & SECAL & 70 & - & - & 70 \\
$08-02-1988$ & Agriculture & SECAL & 200 & - & - & 200 \\
$12-28-1988$ & Structural Adjustment & SAF & - & - & 515 & 515 \\
$03-28-1989$ & Financial & SECAL & 150 & - & - & 150 \\
$06-29-1989$ & Energy & SECAL & 250 & - & - & 250 \\
$11-01-1993$ & Structural Adjustment & SAF & - & - & 1550 & 1550 \\
\hline
\end{tabular}

Sources: Figures for SECAL 1980, 1985, 1986 and SAL 1982, [Nicholas (1988), 42, 45].

Figures for SECAL 1988, 1989, [Jaspersen and Sharif (1990), 24].

Figures for SAF 1988, [Landell-Mills (1991), 6].

Figures for SAF 1993, Newspaper report.

*The IMF agreed to provide a second SAF loan in November 1993, but the disbursement was delayed until February 1994, conditional upon implementation of the suggested measures. Thus, the second SAF is not included in the analysis. 
important suggested policies were: (i) improving domestic resource mobilisation measures; (ii) changing key policies designed for the industrial and foreign trade sectors; (iii) checking the persistent increase in the balance of payments deficit, and (iv) reducing unnecessary public expenditure, and as a consequence reducing the government budget deficit. The sectoral adjustment loans for fertiliser and agriculture focused on increasing agricultural production and improving rural incomes through raising producer's prices so that they would be closer to international market prices and cutting input and consumer subsidies. An export development loan was provided to Pakistan for the expansion of industrial exports. This loan would provide improved incentives through better and cheaper access to imports for exporters and an extended export finance scheme. The first energy loan to Pakistan was approved in May 1985 and the second in June 1989. These loans were to support the government's energy strategy, which was formulated with the assistance of the World Bank. This strategy addressed three principal issues: (i) to rationalise investment and promote integrated development of the energy sector; (ii) to rationalise energy prices; and (iii) to improve operating efficiency and encourage private sector involvement in energy development. The financial sector adjustment loan was provided to reduce the shortcomings of the financial sector. The liberalisation of the financial system remained the main focus of adjustment packages.

The structural adjustment facility (SAF) was created by the IMF in 1986 with resources of SDRs 2.7 billion. Pakistan received the largest share, 19.3 percent of total SAF given to 32 low-income countries. The SAF-supported program focused on four essential areas: (i) raising price incentives for agricultural producers; (ii) increasing domestic savings; (iii) easing bottlenecks on supply and fiscal management; and (iv) liberalising exchange and trade systems.

During the 1980s, the relevant literature in Pakistan did not devote much attention to evaluating structural adjustment lending/packages based on a sound quantitative framework. Nicholas (1988) and Balassa (1989) have done some basic work based on time trends of macroeconomic performance indicators of Pakistan's economy. These studies assume that the increasing or decreasing trends in macroeconomic indicators are due to adjustment reforms, and ignore the effects of all other important factors (e.g. weather, terms of trade, other internal and external borrowing, domestic and foreign interest rates, imported inflation, etc.). These variables can also explain variations in macroeconomic performance indicators. More recently, Naqvi and Sarmad (1993); Vos (1993) and Jansen (1993) provide 
some quantitative insight in this respect. ${ }^{1}$ Naqvi and Sarmad (1993) explain the nature of the external shocks, the importance of the compensatory external flows, and the relevance of the domestic response variables in the adjustment process in Pakistan. Vos (1993) discusses the simulation results based on an initial CGE model for Pakistan that a 50 percent increase in additional foreign assistance in the form of grants would generate a 'Dutch Disease' effect in Pakistan-that is the aid has a direct impact on government consumption and thus on the demand for non-tradable goods (e.g. services) over the next five years (1985-90). Although this study provides some useful analysis, it is based on a hypothetical increase in foreign assistance to Pakistan. It would be more useful to examine whether or not the actual amounts of adjustment finance (instead of assumed amounts) have produced the 'Dutch Disease' effect. In his comparative analysis study, Jansen (1993) concludes that for five countries (Mexico, Pakistan, Thailand, Tanzania, and the Philippines) different types of foreign finance are associated with different policy problems and quite different outcomes in these countries. In a nutshell, the earlier studies based on trends of macroeconomic indicators and on quantitative approaches do not provide the direct effects of structural adjustment lending on key macroeconomic variables. This paper, therefore, considers the weaknesses of earlier studies and provides an empirical analysis of Bank-IMF adjustment lending on Yakistan's key macroeconomic performance indicators using the latest available time-series data.

\section{METHODOLOGY}

Of the various methodologies ${ }^{2}$ that have been proposed to evaluate the effectiveness of adjustment lending, this paper employs two. The first is the so-called 'with-without', which was commonly employed in the $1980 \mathrm{~s}^{3}$ Though it provides a useful starting point, this method suffers, however, from a number of methodological weaknesses. Under this approach, macroeconomic performance indicators such as real GDP growth, export and import growth, current account balance, budget deficit, domestic inflation, and growth in capital formation are compared from one decade without the provision of Bank-Fund adjustment lending and from another decade with the availability of this funding. But this method of

${ }^{1}$ All these studies are unpublished and the preliminary results were discussed in a conference recently organised by the Institute of Social Studies, The Hague, The Netherlands, December 2-3, 1993.

${ }^{2}$ For a detailed discussion and comparison of various methodologies, see Robinson (1988) and Taylor (1990). (1991).

${ }^{3}$ For more detail on this methodology, see Nicholas (1988); Balassa (1989) and Mosley et al. 
evaluation does not seem better because if the economic indicators show some improvements or deteriorations with the SAPs, it cannot be attributed to the programme lending, ignoring the effects of all other extraneous factors.

The second method that will be used here is multiple regression. Under the multiple regression technique, the simple functions of the macroeconomic performance indicators are specified which analyse the impact of Bank-Fund adjustment leading along with other explanatory variables on real output growth, gross fixed capital formation, import demand, export supply, government current consumption, and domestic inflation. The main weakness of this methodology is the direction of causality, which can be overcome by a general equilibrium framework. Therefore, one can argue that the regression results are better than under the with-without approach, but worse than with general equilibrium analysis. Another limitation of this analysis is that it is restricted to a small number of observations (e.g. 1979-91) because the first adjustment lending started in 1980 and the last in 1991. The sources and the definition of variables are given in Appendix. The functions are specified as below.

\section{(i) Real Economic Growth}

The growth of real output ( $G D P g$ ) is assumed to depend on adjustment lending $(A L s)$, other foreign borrowing $(O L)$, the growth rate of real domestic savings ( $R D S g$ ), changes in the terms of trade ( $\triangle T O T)$, and weather conditions $(W T)$. The relevant variables are taken as a percentage of gross domestic product $(Y)$ throughout the analysis. The output function is specified as:

$$
\begin{aligned}
& G D P g=\alpha_{0}+\alpha_{1}[A L s / Y]_{t-1}+\alpha_{2}[O L / Y]_{t-1}+\alpha_{3} R D S g_{t-1}+
\end{aligned}
$$

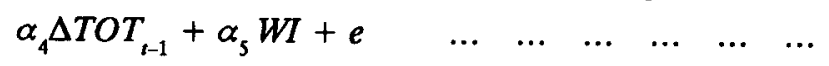

While there are alternative arguments about the impact of foreign capital inflows on real economic growth, ${ }^{4}$ this is clearly an empirical question, and will be examined in the next section. The growth rates of real domestic savings-domestic resources-are assumed to have a positive impact on output growth. It is noted that both of the sources of capital (e.g. foreign savings and domestic savings) are taken one year lagged assuming that the productivity of capital starts at least after

${ }^{4}$ Well-known debate on this issue, include Chenery and Strout (1966); Papanek (1973); Voivodas (1974); Stoneman (1975); Mosley (1980) and Park (1987), who all argue that foreign capital inflows stimulate economic growth in recipient countries. Alternatively, Griffin and Enos (1970); Weisskopf (1972); Fry (1980) and Vos (1988) claim that the availability of foreign capital inflows has a depressing effect on the rate of growth of recipient countries. 
one year (e.g. gestation period). Since 1980, Pakistan's terms of trade have been deteriorating, it could, therefore, be expected that this development may discourage the production of exportable goods, leading, consequently, to a decline in economic growth. Like imperfect forecasting of the weather, its impact on economic growth is, therefore, indeterminate a priori.

\section{(ii) Capital Formation}

Capital formation $(I)$ is assumed to be a linear function of both kinds of foreign capital inflows (e.g. $A L s$ and $O L$ ), growth in domestic savings $(D S g)$, the domestic nominal interest rate $(I R)$, and the expected inflation rate $\left(P^{e}\right)$. The estimating function of capital formation is given by:

$$
\begin{aligned}
& I / Y=\beta_{0}+\beta_{1}[A L s / Y]_{t-1}+\beta_{2}[O L / Y]_{t-1}+\beta_{3} D S g+ \\
& \begin{array}{lllllllll}
\beta_{4} I R+\beta_{5} P^{e}+u & \ldots & \ldots & \ldots & \ldots & \ldots & \ldots & \ldots & \ldots
\end{array}
\end{aligned}
$$

Like real economic growth, the effect of adjustment lending and other foreign borrowing on capital formation is also an empirical question (which will be examined in the next section)-that is, either additional foreign lending is used for the expansion of capital formation or only increased current consumption. Moreover, an increase in domestic savings may raise the level of investment. The rising domestic interest rate, which reflects the cost of credit, may adversely affect the level of gross fixed capital formation because it increases the cost of production, reduces the profit and consequently discourages investment, particularly private investment. In addition, an expected increase in inflation may affect positively the level of investment because rational investors may foresee the increasing cost of production in the future.

\section{(iii) Export Supply}

The following specified export supply function consists of both types of foreign borrowing-adjustment lending and other foreign borrowing-and export price index $(E X P I)$ :

$$
X / Y=\delta_{0}+\delta_{1}[A L \mathrm{~s} / Y]_{t-1}+\delta_{2}[O L / Y]_{t-1}+\delta_{3} E X P I+q
$$

Since the effects of adjustment lending and other foreign borrowing on domestic output and investment are unclear, therefore, their impact on export supply is also a priori indeterminate. Moreover, the rising prices of exports may encourage exporters to increase the supply of exportable goods. 


\section{(iv) Import Demand}

The demand for imports of goods $(M)$ is specified as a function of adjustment lending, other foreign lending, a deterioration in the terms of trade ( $\triangle T O T$ ), the capacity of foreign reserves $(F R)$, and nominal exchange rate devaluation $(E R)$. The following equation is specified as an import demand function:

$$
\begin{aligned}
& M / Y=\gamma_{0}+\gamma_{1}[A L s / Y]_{t-1}+\gamma_{2}[O L / Y]_{t-1}+\gamma_{3} \Delta T O T_{t-1}+
\end{aligned}
$$

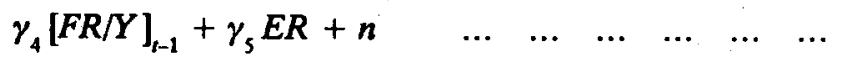

The availability of both types of foreign borrowing is assumed to have a positive impact on the demand for the volume of imports because the provision of hard-currency finance relaxes the foreign exchange constraints, thereby increasing the volume of imports. A devaluation of domestic currency and a deterioration in the terms of trade are assumed to have a negative impact on the volume of imports because both the factors raise the relative prices of imports, thereby reducing the demand for imported goods. In addition, the level of foreign exchange reserves is also included to capture the positive impact that an increasing capacity of foreign reserves may have on the demand for imports.

\section{(v) Government Current Consumption}

Pakistan, like many other developing countries, also depends on foreign sources of finance because of limited domestic resources of public finance. Since the adjustment loans are provided to the government sector rather than to the private sector, therefore, only the government consumption function is specified. The public consumption function incorporates adjustment lending, other foreign borrowing, and government revenue $(G R)$, which allow the following relationship to be specified:

$$
G E / Y=\lambda_{0}+\lambda_{1}[A L s / Y]_{t-1}+\lambda_{2}[O L / Y]_{t-1}+\lambda_{3} G R / Y+f
$$

It is reasonable to assume that the availability of adjustment lending and other foreign borrowing as a foreign source and government revenue (total tax and non-tax revenues) as a domestic source of public finance would enhance expenditure; one would, therefore, expect a priori positive coefficients of all the explanatory variahles in the government consumption function.

\section{(vi) Domestic Inflation}

Domestic inflation $(P)$, estimated from the consumer price index, is specified as function of adjustment lending, other foreign borrowing, the wholesale price 
index of machinery $(P M)$, per capita output (PCh), the stock of real money $(M S)$, and the domestic real interest rate $(R I R)$. The domestic inflation function is given by:

$$
\begin{aligned}
& P=\zeta_{0}+\zeta_{1}[A L \mathrm{~s} / Y]_{t-1}+\zeta_{2}[O L / Y]_{t-1}+\zeta_{3} P M+\zeta_{4} P C I_{t-1}+
\end{aligned}
$$

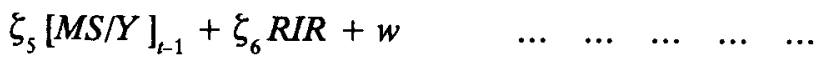

As can be expected, both types of foreign funding are assumed to raise the rate of inflation because the availability of additional external finance may encourage government current consumption, particularly in services, with its logical consequence an increase in the rate of inflation in the economy. Moreover, the prices of machinery are included as an explanatory variable to capture the influence of both domestic as well as imported sources of inflation in the manufacturing sector; the impact of this variable on domestic inflation is therefore, assumed $a$ priori to be positive. In addition, the domestic rate of inflation is expected to respond negatively to the increasing level of output because the higher the supply of output is, the lower will be the inflation rate. The increasing stock of real money may also create inflationary pressure in the economy. Finally, the domestic real interest rate is assumed to be negatively related to domestic inflation because a higher real interest rate may depress current consumption and stimulate domestic savings, as a consequence, a decline in the rate of inflation. ${ }^{5}$

\section{PAKISTAN'S KEY MACROECONOMIC PERFORMANCE INDICATORS}

The data regarding key macroeconomic variables such as real economic growth, gross fixed capital formation, exports and imports of goods, the current account balance, government revenue, government expenditure, the budget deficit, terms of trade, and domestic inflation are divided into two sub-periods: 1970-79 and 1980-91. Using two sub-periods allows for comparison of the performancé indicators of Pakistan's economy for one decade without the availability of the adjustment lending and for the other decade with the provision of this financing. Table 2 reviews the performance of the key macroeconomic variables.

One of the important objectives of Bank-Fund adjustment lending is to foster the current and future real economic growth of LDCs. Table 2 shows that the average annual growth in real GDP - real economic growth - increased considerably from 4.4 percent to 6.3 percent during the period of adjustment in Pakistan.

${ }^{5}$ For more discussion on the relationship between the domestic real interest rate and the inflation rate, see Doroodian (1993). 


\section{Table 2}

Pakistan's Macroeconomic Performance Indictors

1970-79 1980-1991

(Annual Average)* (Annual Average)

\begin{tabular}{lrr} 
Real GDP Growth ( percent) & 4.4. & 6.3 \\
Investment as a Percent of GDP & 15.1 & 17.0 \\
Current Account Deficit as Percent of GDP & -5.9 & -4.2 \\
Exports of Goods as a Percent of GDP & 8.0 & 10.4 \\
Imports of Goods as a Percent of GDP & 13.3 & 18.0 \\
Budget Deficit as Percent of GDP & -5.2 & -7.7 \\
Government Revenue as Percent of GDP & 15.3 & 17.1 \\
Government Expenditure as Percent of GDP & 20.5 & 24.8 \\
Changes in Terms of Trade (Percent) & -1.7 & -4.3 \\
Domestic Inflation Rate (Percent) & 12.7 & 7.9 \\
\hline
\end{tabular}

Source: The data regarding GDP and gross fixed capital formation (investment) are taken from International Financial Statistics, Year Book, IMF (1992). The export and import of goods, the current account balance, government revenue and expenditure, the unit value of imports and exports (for terms of trade), and the consumer price index (for inflation) are taken from Pakistan Economic Sunvey (1985, 1992).

* Government revenue, government expenditure, and the budget deficit are based on an average of the measurements during the period 1972-79.

This trend echoes Nicholas (1988); Balassa (1989) and Mosely et al. (1991), who all argue that Pakistan is among those few recipient countries which benefited in terms of real economic growth from Bank-Fund adjustment lending. This conclusion will be tested based on an empirical analysis incorporating other explanatory variables along with adjustment lending in a real growth function for Pakistan. Table 2 shows that the share of investment in GDP increased from an annual average of 15.1 percent during 1970-79 to 17.0 percent during 1980-91 (the adjustment period). It is assumed that the additional adjustment lending enhanced capital formation in Pakistan, which will also be examined empirically in the next section.

Turning to the external account. Table 2 delineates the trends in the annual average balance of payments on current account, and in exports and imports of goods as a percentage of GDP. The current account deficit as a percentage of GDP decreased considerably from 5.9 percent during 1970-79 to 4.1 percent during 1980-91. Many studies, e.g. Khan (1987); Balassa (1989); Nicholas (1988); Mosley et al. (1991) and Doroodian (1993) found that a large number of recipient countries including Pakistan experience an improvement in their current balances during the adjustment period. It is also argued that a depreciation of the domestic exchange 
rate suggested in the Bank-Fund adjustment packages raised the relative price of tradeable goods to non-tradeable goods, leading to an increase in the volume of exports and a decrease in the current account balance. Moreover, during the 1980s, Pakistan also received huge worker's remittances which further reduced this account. ${ }^{6}$ Table 2 also shows the trends in exports and imports of goods during the period 1970-79 and 1980-91. The average annual exports as a percentage of GDP rose from 8.0 to 10.4. The trend of increasing exports for Pakistan is encouraging. The imports performance for the SAPs period reveals a rise from 13.3 percent to 18.0 percent of GDP. This increasing trend is assumed to exist because of the provision of hard currency under adjustment lending, which releases the balance of payment constraints, thereby increasing the imports bill, which is also an empirical question to be tested.

Table 2 shows that the government revenues increased from 15.3 percent to 17.1 percent and government expenditure from 20.5 percent to 24.8 percent of GDP, with a consequent increase in the budget deficit from 5.2 percent to 7.7 percent of GDP during the periods 1972-79 and 1980-91, respectively. Domestic inflation, measured from the consumer price index reported in Table 2, shows a considerable declining trend. The average annual inflation rate during 1970-79 and 1980-91 fell from 12.7 percent to 7.9 percent. Regarding terms of trade, Pakistan experience a substantial deterioration, from 1.7 percent to 4.3 percent during the periods under consideration (which is not surprising because Pakistan, like other developing countries, was also badly affected by the world recession and declining international prices of exports, particularly agricultural exports). At the same time, the prices of imported goods, particularly manufactured goods and machinery, increased considerably, with a corresponding deterioration in the terms of trade.

\section{EMPIRICAL RESULTS}

The econometric technique here has been kept simple and ordinary least squares (OLS) estimation procedure has been used. The relevant variables are taken as a ratio to GDP to avoid the problem of multicollinearity among explanatory variables. The preferred results are reported in Table 3, where 'preferred' refers to those equations that produced the expected signs of coefficients, the minimum standard errors, and reasonable values of the adjusted coefficient of determination $\left(R^{2}\right)$. Furthermore, the often small samples make interpretation of the econometric

\footnotetext{
${ }^{6}$ For further detail on this, see Naqvi and Sarmad (1993) and Jansen (1993).
} 


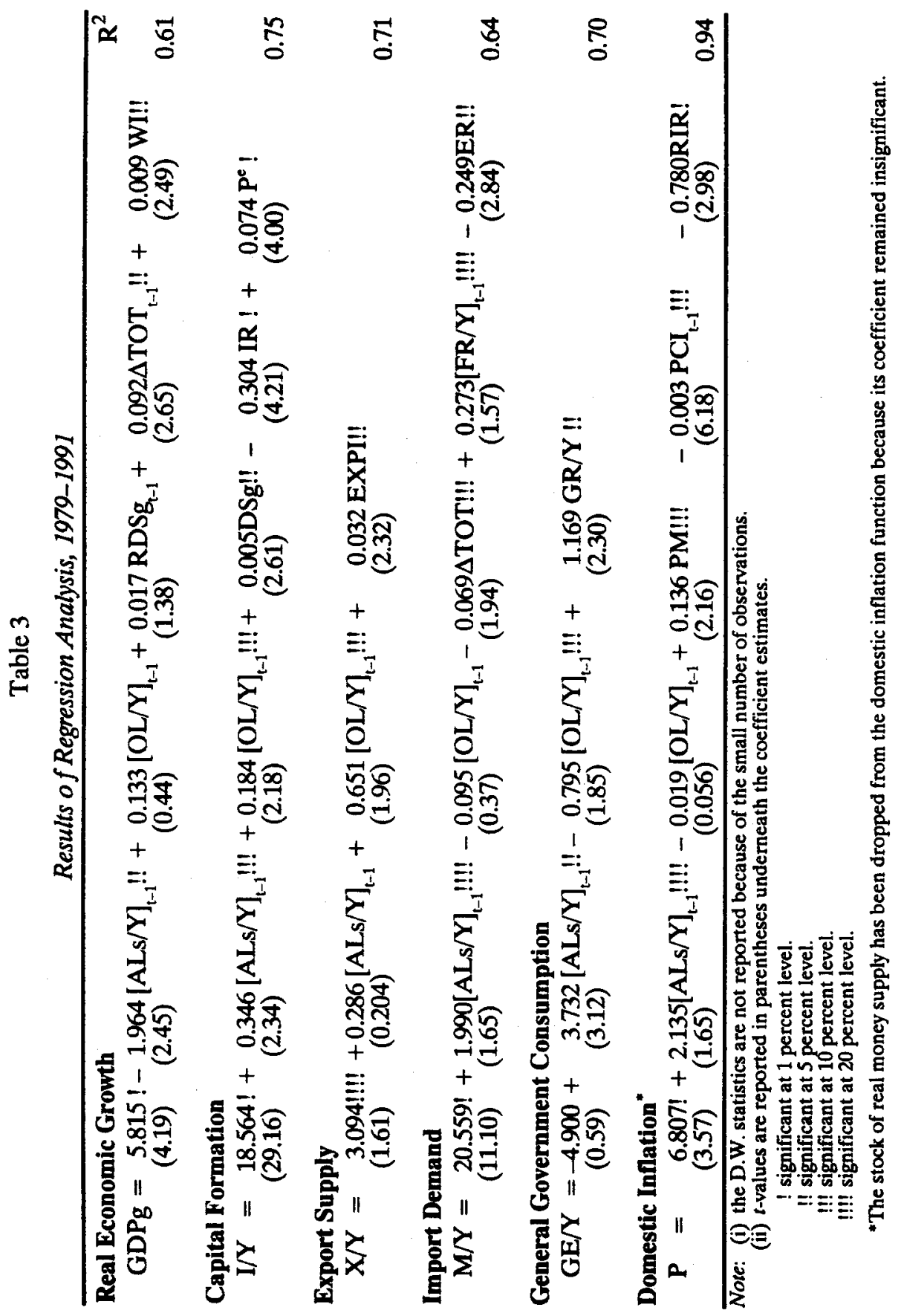


results more difficult; the regression results are therefore suggestive and cannot be treated as definitive. A possible explanation of the results is given in the following paragraphs.

Growth in real GDP is taken as a performance indicator for real economic growth. The coefficient of the Bank-Fund adjustment lending does not appear to affect positively Pakistan's real output growth. It possesses a negative sign, which does not support Table 2's finding that Pakistan experienced an increase in real economic growth with the additional adjustment finance. The coefficient of other foreign borrowing has a positive sign but remains insignificant. A possible explanation is that the adjustment lending does not provoke an immediate response in output growth because it has a long gestation period. This finding also seems to support the argument of Griffin and Enos (1970), that a large proportion of publicly sponsored foreign assistance channels into non-productive activities, altering the composition of investment, and raising the capital-output ratio, and as a consequence retarding the economic growth of the aid-receiving country. This situation brings to mind similar arguments by Khan and Knight (1985); Khan (1987); Faini et al. (1990); Vos (1993) and Doroodian (1993) who all argue that the decline in real economic growth in LDCs is a necessary part of adjustment (e.g. a reduction in aggregate demand and an elimination of underlying imbalances in their economies). Some writers e. g. Killick (1984) argue that Bank-Fund programmes do little in improving the economic conditions in recipient countries while other e.g. Taylor (1981) claim that adjustment programmes have worsened the economic situation in LDCs. All other explanatory variables in the output growth function have expected signs. Favourable weather has a positive effect on GDP growth rates. The coefficient of domestic real saving growth-domestic resources -possesses a positive sign but it remains weaker at the required significance level. According to a priori expectation, the deterioration in the terms of trade has a negative effect on real output (note: $\triangle T O T$ is a negative variable).

Gross domestic investment as a share of GDP is taken as an indicator of the substantial long run economic growth of Pakistan's economy. The estimated investment function produces robust results. Coefficients of the provision of adjustment finance and other external borrowing have a positive and significant impact on capital formation. The marginal propensity to invest out of adjustment lending and other external borrowing is 0.35 and 0.18 respectively, implying that the availability of adjustment lending has increased almost doubled the investment share in GDP as compared to other external finance. This result shows that a substantial part of adjustment lending is invested into productive activities because 
of strict adherence to conditions. As the other foreign loans are relatively less conditional, a relatively small proportion is therefore used to enhance capital formation. This result also supports the findings of the tabular method reported in Table 2 that the gross fixed capital formation in Pakistan increased during 1980-91. In addition, the growth rate of domestic savings-the available domestic resources-has a positive and significant effect on domestic investment. The domestic interest rates, which reflect the cost of credit, are negatively related with investment, supporting the view that higher interest rates discourage investment, particularly private investment, in Pakistan. The expected increase in inflation also raises the current level of investment, implying protection of increasing cost of production and earning higher profits in the future.

Estimation of the export supply function indicates that adjustment inflows have no significant effect on exports. The insignificant effect of adjustment finance on exports is not surprising and it also supports the findings of the real economic growth function that adjustment lending is not positively correlated with Pakistan's economic growth, with its consequence of no increase in export earnings in the short run. The impact of two other important explanatory variables, namely the other external borrowing as a share of GDP and the export price index, are found to be statistically significant with a positive sign. The data regarding the export price index also reveal a remarkable increase since 1980, providing an incentive to enhance exports of domestic goods.

The estimated import demand function also produces sensible results. Bank-Fund adjustment lending has a positive impact on imports as a share of GDP. This result supports the argument that the provision of hard-currency finance relaxes the balance of payments constraint on imports, thereby increasing the level of imports. Moreover, the adjustment packages for Pakistan also include the removal of quantitative restrictions on imports, reforms of import tariffs, and removal of foreign exchange control; all these policies may also therefore encourage the level of imports. The results concerning the other explanatory variables, namely deterioration in the terms of trade and a devaluation in the domestic currency (Pak. rupees per US dollar), have a negative impact on the demand for imports, suggesting that the higher the prices of imported goods are, the lower will be the demand for imports. Following a priori expectation, the foreign exchange reserves as a ratio to GDP has a positive effect on Pakistan's imports, supporting the idea that the higher reserves capacity of foreign exchange may increase the level of imports. The impact of other external borrowing remains insignificant, providing inconclusive results. 
The estimated equation for government current consumption indicates that the adjustment lending has a positive impact and is significantly different from zero at the 5 percent level. It seems that adjustment lending produces the so-called 'Dutch Disease effect' in Pakistan because such lending has a direct effect on government consumption and thus on the demand for non-tradeable goods (e.g. services). Contrary to adjustment lending, other external finance has an unexpectedly negative effect on government consumption. The coefficient of government revenue is positive and significantly related with government consumption. The marginal propensity to consume out of government revenue is 1.17 , which implies that government expenditure has not been constrained within available government ' domestic resources.

Another key performance indicator-the domestic inflation rate-whose development is also followed closely by Bank- Fund adjustment lending programmes, is taken for empirical analysis. Findings in Table 2 show that the inflation rate in Pakistan decelerated during the adjustment period, but the regression results do not follow the tabular results. This result is as expected and is also supported by the government consumption function that the availability of external finance encourages current consumption, particularly public consumption in services, and as a consequence an increase in the rate of inflation in the economy. The other explanatory variables such as the domestic real interest rate and per capita output decelerate the rate of domestic inflation, which could be expected, and the domestic real interest rate appears to be more effective in curbing the domestic inflation rate in Pakistan. The other factor accelerating inflation is the increasing cost of manufacturing, which is affected by both domestic as well as imported inflation. The coefficient of other external foreign inflows remains insignificant, leaving us thereby inconclusive.

\section{CONCLUSIONS}

Since 1980, Pakistan has received eight structural and sectoral adjustment loans worth a total of \$ 1553 million from the World Bank, the IDA and the IMF. These loans were conditional upon correction of the internal and external imbalances of the economy. This paper uses the 'with-without approach' and the regression analysis approach to analyse whether there is any direct connection between adjustment lending and Pakistan's key macroeconomic variables. Under the withwithout approach, the trends of various macroeconomic performance indicators e.g. real economic growth, gross fixed capital formation, exports and imports of goods, the current account balance, government revenue, government expenditure, 
the budget deficit, terms of trade, and domestic inflation have been compared for the periods 1970-79 (without adjustment) and 1980-91 (with adjustment). But such trends, sometimes, provide us with misleading results because they are derived by ignoring the impact of other explanatory variables on the performance indicators. As the main objective of this study is to analyse the direct effects of structural adjustment lending on Pakistan's key macroeconomic variables, therefore, the multiple regression technique is also used for analysis. An attempt was made to separate the impact of adjustment lending from other explanatory variables (taking the data for the period 1979-91), but due to danger of causality and the small number of observations, however, these results should be treated merely as suggestive.

If the tabular findings of Section III are to be believed, then Pakistan's macroeconomic performance with respect to real economic growth, capital formation, exports of goods, current account balance, and domestic inflation have improved during the adjustment period, while the import of goods and the government current consumption have increased, and terms of trade have deteriorated. But these findings do not coincide with regression results, which are relatively more robust. The findings of the regression technique show that real output declined, the inflation rate increased, and exports of goods remained insignificant with the availability of adjustment lending, which contradicts the tabular results. The performance of other indicators (e.g. investment, imports of goods, and government consumption) follow the tabular results: these variables all increased during the period with the adjustment lending and during the adjustment period. An important finding in this paper is that adjustment lending seems to enhance capital formation more than other foreign borrowing does because of relatively more strict conditions imposed on the productive use of adjustment finance. The finding also shows that adjustment lending not only enhances investment but also increases the government's current consumption because a large part of these loans is used for government current consumption, which produces the so-called Dutch Disease effect in Pakistan. Further work, of course, needs to be done on these associations using economy-wide models of one kind or another. 
Appendix

Definitions of Variables

\begin{tabular}{|c|c|}
\hline Variables & Definitions \\
\hline $\begin{array}{r}Y \\
\text { GDPg } \\
\text { ALs/Y }\end{array}$ & $\begin{array}{l}\text { gross domestic product (GDP) at current market prices. } \\
\text { annual growth rates in real GDP at constant prices of } 1980-81 \text {. } \\
\text { adjustment lending (structural plus sectoral adjustment loans) provided by the World } \\
\text { Bank, the IDA, and the IMF as a percentage of GDP. It is assumed that } 50 \text { percent of a } \\
\text { loan is disbursed in the year of loan approval by Bank-Fund Board and the remaining } 50 \\
\text { percent of equal shares over the subsequent two years. This assumption does not, } \\
\text { however, always reflect the actual disbursement pattern of SAL and SECAL loans. This } \\
\text { generalisation is supported by [Jaspersen and Sharif (1990), 10] who describe that a } \\
\text { typical adjustment loan is disbursed in two loans; [Nicholas (1988), 22] mentioned that } \\
\text { all SAL and SECAL are trenched into two or three loan trenches as agreed-upon policy } \\
\text { reforms are implemented; and [Mosley (1991), 239] used two equal trenches of SAL and } \\
\text { SECAL loans over two years. }\end{array}$ \\
\hline OL $\mathbf{Y}$ & $\begin{array}{l}\text { other external borrowing as a percentage of GDP. It is calculated as an annual change } \\
\text { in total debt outstanding minus adjustment lending (ALs). } \\
\text { annual growth rates in nominal domestic savings. }\end{array}$ \\
\hline RDSg & $\begin{array}{l}\text { annual growth rates in real domestic savings. Nominal domestic savings are deflated by } \\
\text { GDP deflator to get real savings. }\end{array}$ \\
\hline$\Delta \mathrm{TOT}$ & $\begin{array}{l}\text { change in terms of trade defined as a percentage change in the ratio of index of export } \\
\text { prices to the index of import prices. }\end{array}$ \\
\hline EXPI & export price index. \\
\hline $\mathbf{I} / \mathbf{Y}$ & gross domestic capital formation as a percentage of GDP. \\
\hline FR/Y & foreign exchange reserves (cash) as a percentage of GDP. \\
\hline ER & nominal exchange rate. It is calculated as Pakistani rupees per US dollar. \\
\hline WI & $\begin{array}{l}\text { weather index proxied by the average rainfall in capital cities of Pakistan for the period } \\
\text { stated as a percentage of the } 45 \text {-years average (1947-1991). }\end{array}$ \\
\hline IR & annual average nominal interest rates on fixed deposits. \\
\hline RIR & real interest rate defined as nominal interest rate minus inflation rate. \\
\hline $\mathbf{P}^{\mathbf{e}}$ & $\begin{array}{l}\text { inflation rate calculated from consumer price index and one-year lagged is taken as } \\
\text { expected. }\end{array}$ \\
\hline $\mathbf{X} / \mathbf{Y}$ & exports of goods as a percentage of GDP. \\
\hline $\mathbf{M} / \mathbf{Y}$ & imports of goods as a percentage of GDP. \\
\hline PM & Wholesale price index of machinery. \\
\hline $\mathbf{G E} / \mathbf{Y}$ & general government consumption as a percentage of GDP. \\
\hline PCI & per capita GDP. \\
\hline GRY & government revenue as a percentage of GDP. \\
\hline $\begin{array}{r}\mathrm{MS} / \mathrm{Y} \\
\mathrm{u}, \mathrm{q}, \mathrm{n}, \mathbf{f}, \mathbf{w}\end{array}$ & $\begin{array}{l}\text { stock of real money supply }\left(\mathrm{M}_{2}\right) \text { as a percentage of GDP. } \\
\text { stochastic error terms. }\end{array}$ \\
\hline
\end{tabular}

Sources: The sources for ALs are already mentioned in Table 1. Annual change in total debt outstanding, the index of export prices, the index of import prices, foreign exchange reserves, average rainfall in capital cities, consumer price index, total exports and imports of goods, the wholesale price index of manufactures, and government revenue, are taken from Pakistan Economic Survey $(1985,1992)$. The time-series data for domestic interest rates are available in the Annual Report, State Bank of Pakistan (1978, 1987, 1991). The gross domestic product, gross domestic savings, gross fixed capital formation, general government consumption, and nominal exchange rates are taken from International Financial Statistics Yearbook, IMF(1992). 


\section{REFERENCES}

Balassa, B. (1989) A Quantitative Appraisal of Adjustment Lending. The Pakistan Development Review 28:2 73-94.

Chenery, H., and A. M. Strout (1966) Foreign Assistance and Economic Development. The American Economic Review 56:4 679-733.

Doroodian, K. (1993) Macroeconomic Performance and Adjustment under Policies Commonly Supported by the International Monetary Fund. Economic Development and Cultural Change 41:4 849-864.

Faini, R., J. de M., A. S. Semlali, and J. Stanton (1990) Growth-oriented Adjustment Programmes: A Statistical Analysis. The World Bank: Country Economic Department. (Working Papers, WPS 426.)

Fry, M. (1980) Savings, Investment, Growth and the Cost of Financial Repression. World Development 8:4 317-327.

Griffin, K., and J. L. Enos (1970) Foreign Assistance: Objectives and Consequences. Economic Development and Cultural Change April 313-327.

Jansen, K. (1993) Structural Adjustment and Economic Recovery: A Comparative Analysis of Economic Policy. Paper presented in an International Policy Workshop on International Capital Flows and Economic Adjustment in Developing Countries organised by the Institute of Social Studies. The Hague: The Netherlands. December, 2-3.

Jaspersen, F., and K. Sharif (1990) The Macroeconomic Underpinnings of Adjustment Lending. The World Bank: Country Economics Department (October). (Working Papers, WPS 511.)

Khan, M. S. (1987) Stabilisation and Economic Growth in Developing Countries. The Pakistan Development Review 26:3 341-361.

Khan, M. S., and M. D. Knight (1983) Determinants of Current Account Balances of Non-oil Developing Countries in the 1970s. IMF Staff Papers 30: 819-842.

Khan, M. S., P. Montiel and N. Haque (1990) Adjustment with Growth: Relating the Analytical Approaches of the IMF and the World Bank. Joumal of Development Economics 32.

Landell-Mills J. (eds) (1991) Helping the Poor: The IMF's New Facilities for Structural Adjustment. Washington, D.C.: IMF. External Relations Department. Mosley, P. (1980) Aid, Savings and Growth Revisited. Oxford Bulletin of Economics and Statistics 42:1 79-95.

Mosley, P., J. Harrigan and J. Toye (eds) (1991) Aid and Power, The World Bank and Policy-based Lending 1. London and New York: Routledge.

Mosley, P., J. Harrigan and J. Toye (eds) (1991a) Aid and Power, The World Bank 
and Policy-based Lending 2. Case Studies. London and New York: Routledge. Naqvi, S. N. H., and K. Sarmad (1993) External Shocks and Domestic Adjustment: Pakistan's Case 1970-1990. Islamabad: Pakistan Institute of Development Economics. Paper presented in an International Policy Workshop on International Capital Flows and Economic Adjustment in Developing Countries organised by the Institute Social Studies. The Hague: The Netherlands. December, 2-3.

Nicholas, P. (1988) The World Bank's Lending for Adjustment: An Interim Report. Washington, D.C.: The World Bank. (World Bank Discussion Papers 34.)

Papanek, G. (1973) Aid, Foreign Private Investment, Savings, and Growth in Less Developed Countries. Joumal of Political Economy 81:1 120-130.

Pakistan, State Bank of (Various Issues) Annual Report. State Bank of Pakistan. Pakistan, Government of (Various Issues) Economic Survey. Islamabad: Economic Advisor's Wing, Finance Division.

Park, Hui-Jong (1987) The Effects of Foreign Capital Inflow on Economic Growth in Korea: The Reevaluation of Griffin and Enos's Hypothesis. International Economic Joumal 1:2 79-93.

Robinson, S. (1988) Multisectoral Models. In H. B. Chenery and T. N. Srinivasan (eds) Handbook of Development Economics II. Amsterdam: North-Holland. 885-947.

Stoneman, C. (1975) Foreign Capital and Economic Growth. World Development 3:1 11-26.

Taylor, L. (eds) (1990) Socially Relevant Policy Analysis, Structuralist CGE Models for the Developing World. Cambridge: MIT Press.

Voivodas, C. (1974) Exports, Foreign Capital Inflow and South Korean Growth. Economic Development and Cultural Change 22:3 480-484.

Vos, R. (1988) Savings, Investment, and Foreign Capital Flows: Have Capital Markets become Integrated. The Journal of Development Studies 24:3 311-333. Vos, R. (1993) External Finance and Adjustment: A Comparative General Equilibrium Analysis Applied to Pakistan. The Philippines and Thailand. Paper presented in an International Policy Workshop on International Capital Flows and Economic Adjustment in Developing Countries organised by the Institute of Social Studies. The Hague: The Netherlands. December, 2-3.

Weisskopf, T. (1972) The Impact of Foreign Capital Inflow on Domestic Savings in

Underdeveloped Countries. Journal of International Economics 2: 25-38.

World Bank (1985) World Development Report. New York: Oxford University Press. 


\section{Comment on \\ "Macroeconomic Effects of Adjustment \\ Lending in Pakistan"}

This is a very important paper because it deals with the most sensitive and also the most avoided issue in Pakistan. Structural adjustment lending has become a way of life with every government, and the attached conditionalities are the favourite subject of its opponents. Keeping in view the vast debate about conditionalities, and the controversy over the purely monetary performance criteria without due consideration to the structural bottlenecks of the LDCs, I have the following comments.

First, the time series econometric testing approach adopted in this paper and the results reported showing that "all is well" with the additional funding, is brushing the real issue under the rug.

Second, the time series regression presented here appears to be a simple exercise of the determinants of major macro variables. The performance of these variables will vary according to the severity of the underlying structural, institutional and economic factor in that period. Moreover, in agrarian economies climatic conditions are an equally important factor. Therefore, it is not appropriate to put them in a time series framework. This subject of time frame has been at the centre of the literature on adjustment lending in Latin American, Asian and South-Asian countries see Killick (1982); Killick et al. $(1984,1984 a)$ and Cline and Weintruab (1981). Almost all these studies have highlighted the underlying factors behind the success or failure of a programme by looking at the economic, socio-political and institutional factors before, during and after each adjustment programme in any country.

Three, contrary to the results presented here which show that additional adjustment lending affects almost all the variables positively, studies have shown adverse impacts of adjustment lending due to policy conflicts between the developed and developing countries. One common factor that has affected the performance of most of the the LDCs under the adjustment programmes, is the protectionist policies of the developed countries. A major objective of all adjustment lending programmes is to reduce the debt burden of the poor countries by increasing their exports. The policy variable for this strategy is the liberlisation of 
imports. However, this strategy does not ensure protection against the trade and tariff barriers of the developed countries blocking the exports of LDCs. Consequently these countries end up accumulating more debt rather than reducing it.

Four, in studying the impact of the adjustment lending the outcome of certain variables according to the predictions of the lending agencies is important for them. However, from the point of view of the country implementing the programme what is more important is the impact of the control variables on the income distribution, employment and poverty during and after the programme period. In this connection I would like to refer the author to the paper by Dr Kemal (1994) presented in this conference. The second relevant reference in this regard is Khan (1993).

Five, in this paper the approach adopted in Table 3 is a step in the right direction. However, the use of ten years average data is not desirable. These variables should be compared over each programme period. This will help clarify the situation prevailing in every programme period with reference to the prevailing structural, institutional, socio-political and economic constraints for that period. Such comparisons over different programme periods will help in identifying the most critical and perpetual structural and other factors affecting some of the most important macro-variables.

The author does not pursue the approach adopted in Table 3 because the outcome is not in conformity with the empirical results. This is very surprising because the divergence in results is obviously due to the techniques involved.

Finally, with reference to Table 3, remittances may also be included because they have been one of the important factors affecting the performance of the external sector in the adjustment programmes [Firoze (1986)].

The Pakistan Institute

Faiz Bilquees

of Development Economics, Islamabad.

\section{REFERENCES}

Cline, W. R., and S. Weintruab (1981) Economic Stabilisation in Developing Countries. Washington, D.C.: The Brookings Institution.

Firoze, B. F. (1986) The Origins of Inflation of Pakistan 1959-82: An Evaluation of Alternative Hypothesis. Unpublished Ph. D. Thesis. University of Manchester U. K. 